\title{
Bioremediation of Heavy Metals by Serious Aquatic Weed, Salvinia
}

\author{
Sweta Kumari ${ }^{1}$, Baidyanath Kumar $^{2 *}$ and Rimjhim Sheel ${ }^{3}$ \\ ${ }^{1}$ Research Scholar, Department of Botany, Ganga Devi Mahila college (Magadh University), \\ Kankarbagh, Patna, India \\ ${ }^{2}$ Visiting Professor, Department of Biotechnology, Patna Science College, Patna, India \\ ${ }^{3}$ Associate Professor and Head, Department of Botany, Ganga Devi Mahila college \\ (Magadh University), Kankarbagh, Patna, India \\ *Corresponding author
}

\section{Keywords}

Heavy metals, phytoremediation, bioaccumulation, hyperaccumulators, Salvinia.

\begin{tabular}{l}
\hline Article Info \\
\hline Accepted: \\
15 August 2016 \\
Available Online: \\
10 September 2016
\end{tabular}

\section{A B S T R A C T}

Salvinia Guettard is a Weed of National Significance and is regarded as one of the worst weeds because of its invasiveness, potential for spread, and economic and environmental impacts. It is an aquatic weed that can choke waterways. It floats on still or slow-moving water and can grow rapidly to cover the entire water surface with a thick mat of vegetation. This shades out any submerged plant life and impedes oxygen exchange, making the water unsuitable for fish and other animals. Heavy metal toxicity and the danger of their bioaccumulation in the food chain represent one of the major environmental and health problems of our modern society. A very promising, environmental-friendly and cost effective alternative is plant based bioremediation or phytoremediation. Aquatic ferns in particular exhibit exorbitant potential to remove various contaminants including heavy metals, organic compounds, radionuclides from the environment. Among various aquatic macrophytes Salvinia, a free-floating aquatic fern holds a distinct position because of high productivity and tolerance to a wide range of temperatures. In the present investigation bioremediation of heavy metal contaminants by three species of Salvinia, viz. S. natans, S. molesta and S. auriculata was studied. It was found that various concentrations of heavy metals caused considerable reduction in the fresh weight and increase in dry weight of all the three species. All the three species of Salvinia showed a decline in fresh weight with increasing concentration of $\mathrm{Cd}, \mathrm{Cu}$, $\mathrm{Cr}, \mathrm{Hg}, \mathrm{Pb}, \mathrm{Ni}$ and $\mathrm{Zn}$. After 10 days of treatment the all the three species of Salvinia showed a substantial amount of accumulation of heavy metals in their tissues. The bioaccumulation of heavy metals increased with increasing the concentration of heavy metals. Salvinia molesta showed maximum accumulation of $\mathrm{Hg}, \mathrm{Ni}$ and $\mathrm{Pb}$ in the concentration of $18575 \mathrm{ppm}, 18875 \mathrm{ppm}$ and $18275 \mathrm{ppm}$ respectively. It can be concluded that Salvinia natans, S. molesta and S. auriculata are efficient in accumulating highest amounts of heavy metals. The results obtained in the experimental study proves the fact that Salvinia natans, S. molesta and S. auriculata have the innate capacity for the accumulation of appreciable quantities of heavy metals. 


\section{Introduction}

Salvinia Guettard is a Weed of National Significance and is regarded as one of the worst weeds because of its invasiveness, potential for spread, and economic and environmental impacts. It is an aquatic weed that can choke waterways. It floats on still or slow-moving water and can grow rapidly to cover the entire water surface with a thick mat of vegetation. This shades out any submerged plant life and impedes oxygen exchange, making the water unsuitable for fish and other animals. The infestation of Salvinia reduces the natural beauty and biodiversity of wetlands and block irrigation, cause flooding, pollute drinking water, and prevent recreational activities such as swimming, fishing and boating. Infestations can be dangerous to animals and people because the mats look like solid ground, and they provide an ideal breeding environment for disease-carrying mosquitoes.

Salvinia is a free-floating water fern that forms dense mats on water. It consists of many branched horizontal stems, $1-2 \mathrm{~mm}$ in diameter, which floats just below the water surface. At each node arises a pair of floating, green, oval-shaped hairy fronds. A brown frond, consisting of many hairy filaments, also occurs at each node and trails in the water, looking and acting like a root. Salvinia changes as it matures and becomes more crowded. In low densities the primary invading plants have a few small floating fronds $(10-15 \mathrm{~mm}$ wide) which lie flat on the water. However, in the dense infestations that cause mats, the many floating fronds are folded, up to $60 \mathrm{~mm}$ wide, overlapping and tightly packed together in a concertina-like fashion. The surfaces of the floating fronds have numerous distinctive egg-beatershaped hairs that repel water and assist floatation.
Salvinia can increase its density by growth (stems can grow up to $300 \mathrm{~mm}$ long) or vegetative reproduction. It grows extremely quickly and infestations can double in size every two to three days. Uninfested areas can quickly become completely covered with salvinia, even when only small amounts are introduced to a waterway. Reproduction occurs when mature plants produce buds at the stem node (the join between sections of the stem) which develop to form daughter plants. It may also occur if a part of the stem containing a node breaks away from the main plant and grows into a new plant. One pair of fronds can start an entire new infestation. Salvinia spreads easily downstream during flooding, but moves into new catchments by human activities. It has been intentionally spread throughout the world as an ornamental pond or aquarium plant, and has escaped or been placed into waterways on numerous occasions. It can also be unintentionally introduced into new catchments attached to boats and other aquatic equipment.

The mats of weed also interfere with swimming and make fishing impossible. As native aquatic plants, birds and animals are displaced, the natural beauty of an open water body can be spoilt and further degraded. Under flood conditions, rafts of weed material build up at fences and bridges that, in turn, collect other floating debris. The combined weight may cause these structures to collapse. Water flow to irrigation equipment is reduced due to the restrictive action of the roots, which in turn increase pumping times and costs. Therefore, Salvinia is listed as a Weed of National Significance.

Salvinia includes thirteen species. All species of salvinia are free-floating aquatic ferns, with small, spongy, green leaves positioned in pairs along a common stem. 
The surface of each leaf is covered with long, stiff, water-repellent hairs. When the plant matures, the leaves become thick and fold at the mid-rib. Salvinia natans, $S$. molesta and $S$. auriculata occur in India. Salvinia natans is found in abundance in Dal lake at Kashmere (Srinagar). Salvinia molesta is found in Kerala State. Salvinia prefers warmer temperatures and, because it's frost sensitive, it produces little growth in winter. When summer temperatures rise, Salvinia increases its vegetative growth. Under optimal growth conditions Salvinia can double in volume every two to three days.

Water pollution is a major global problem and it is leading worldwide cause of deaths and diseases (Pink and Daniel, 2006). According to M.A. Farooqui, scientist, Central Ground Water Board (CGWB), (2011) improper disposal of solid waste causes direct contamination of ground water. The strongest water pollutants are insecticides, pollutants from livestock operations, volatile organic compounds, food processing waste and chemical waste. Heavy metals are the most dangerous type of chemicals since they are serious health hazard. The most common heavy metal contaminants are: Cadmium (Cd), Chromium $(\mathrm{Cr})$, Copper $(\mathrm{Cu})$, Mercury $(\mathrm{Hg})$, Lead $(\mathrm{Pb})$, Nickel $(\mathrm{Ni})$ and Zinc $(\mathrm{Zn})$ (Lasat, 2002). Industrial effluents are the major source of heavy metal pollution. Chromium and Copper are the principal components and have led to the destruction of various aquatic ecosystems. $\mathrm{Cr}$ (VI) is considered as the most toxic form of $\mathrm{Cr}$, which usually occurs associated with oxygen as chromate (CrO4 2-) or dichromate ( $\mathrm{Cr} 2 \mathrm{O} 7$ 2-) oxyanions. $\mathrm{Cr}$ (III) is less mobile, less toxic and is mainly found bound to organic matter in soil and aquatic environments (Bequer et al., 2003). In India, about 2000-32000 tons of elemental $\mathrm{Cr}$ annually escape into the environment from tanning industries. Copper $(\mathrm{Cu})$ concentrations that exceed 20 micrograms per gram $(\mu \mathrm{g} / \mathrm{g})$ can be toxic, as explained by Heike Bradl (Heike Bradl, 2005) and Wright and Welbourn (2002). Heavy metal toxicity and the danger of their bioaccumulation in the food chain represent one of the major environmental and health problems of our modern society. The conventional treatment methods used for removing metal ions are highly expensive. A very promising, environmental-friendly and cost effective alternative is plant based bioremediation or phytoremediation. It was first proposed by R.L. Chaney (1983). Phytoremediation refers to the natural ability of certain plants to bioaccumulate, degrade, or render harmless containments in soil, water, or air through the natural, biological, chemical or physical activities and processes of plants. Certain aquatic plants are called 'hyperaccumulators'. Aquatic ferns in particular exhibit exorbitant potential to remove various contaminants including heavy metals, organic compounds, radionuclides from the environment. Among various species, Salvinia, a free-floating aquatic fern holds a distinct position because of high productivity and tolerance to a wide range of temperatures. Even Pistia stratiotes L. has a great potential to bioaccumulate and is a bioindicator of various heavy metals (Sinha et al., 2006).

The role of aquatic plants in phytoremediation technology is well established (Dushenkov et al., 1995; Rai et al., 1995; Schneider and Rubio, 1999; Skinner et al., 2007). Aquatic ferns in particular exhibit exorbitant potential to remove various contaminants including heavy metals, organic compounds, radionuclides from the environment (Olguín et al., 2002; Benaroya et al., 2004, Stepniewska et al., 2005; Sune et al., 2007). 
Among various species, Salvinia holds a distinct position because of several advantages including high productivity and tolerance to a wide range of temperatures (Olguín et al., 2002). Several species of Salvinia including $S$. herzogii, S. minima, $S$. natans, $S$. rotundifolia show potential to remove various contaminants including heavy metals from wastewaters (Nichols et al., 2000; Olguín et al., 2002; Sune et al., 2007; Sánchez-Galván et al., 2008; Xu et al., 2009). The potential of Salvinia for heavy metal removal has been studied extensively (Srivastav et al., 1993; Banerjee and Sarkar, 1997; Olguín et al., 2002, 2005; Hoffman et al., 2004; Espinoza- uinones et al., 2005; Mukherjee and Kumar, 2005; Molisani et al., 2006; Sune et al., 2007) . The heavy metal removal and compartmentalization in Salvinia is primarily a function of the presence of certain nutrients and chelants, with secondary dependence on environmental conditions (Olguin et al., 2003), though the mode of metal uptake varies depending upon the plant species and metal. The metal uptake in Salvinia occurs through a biological or physical mode. The metal $(\mathrm{Cr}$, $\mathrm{Pb}$ ) uptake by physical processes is fast and involves adsorption, ionic exchange and chelation, while biological processes such as intracellular uptake (transported through plasmalemma into cells) is comparatively slow but help in subsequent translocation of metals $(\mathrm{Cd})$ from roots to leaves (Sune et al., 2007). The maximum uptake occurs during the first few hours, though sorption capacity is limited by availability of adsorption sites. Studies involving scanning electron microscopy microanalysis suggest direct sorption of heavy metals through leaves as they are in direct in contact with the solution (Sune et al., 2007) and propose that as the main cause of increase in metal in the aerial parts (Maine et al., 2004). It has been postulated that uptake of heavy metals is driven by secondary transport proteins viz. channel proteins or $\mathrm{H}+$ coupled carrier proteins where negative membrane potential inside the plasma membrane drives the uptake of cations through secondary transporters. Free carboxylic groups present on the cell surface provide the sites for metal binding (Olguin et al., 2005). High metal removal capacity of Salvinia biomass has been attributed to great specific surface (264 $\mathrm{m} 2 \mathrm{~g}-1)$ that is rich in carbohydrates (48.50\%) and carboxyl groups $(0.95 \mathrm{mmol}$ g-1) (Sánchez-Galván et al., 2008). Proteins behave as important ligand atoms and also play an important role in metal absorption. The kinetics for the metal removal exhibit first order rate and equilibrium data fit well to both Langmuir and Freundlich's isotherms (Mukherjee and Kumar, 2005). Among various Salvinia species, S. minima, is considered as a hyperaccumulator of lead and cadmium because it shows high bioconcentration factor (BCF) (Olguin et al., 2002) which can reach in the range of 20002600 in batch systems and 4134 to 17170 in continuous systems (Olguin et al., 2005). Non-living biomass of Salvinia exhibit equivalently high potential to remove heavy metals. The higher concentration of lipids and carbohydrates present on the plant surface act as the cationic weak exchanger groups that contribute to metal sorption by ion exchange reactions. Sorption of heavy metals by dry biomass also follows the Langmuir isotherm (Schneider and Rubio, 1999).

Another Salvinia species, S. rotundifolia show capacity for treating groundwater contaminated with explosives such as TNT. The removal of TNT by plants is rapid and result in accumulation of metabolic products such as aminodinitrotoluene (ADNT) (Jacobson et al., 2003). Salvinia minima show capacity to treat high-strength synthetic organic wastewater (HSWW). The 
plants raised in HSWW depict potential for fast consumption of inorganic nutrients such as ammonium-nitrogen and nitrate-nitrogen and significant increase in relative growth rate (RGR) and productivity (2.3 fold increase) (containing ammonium-nitrogen concentration of $70 \mathrm{mg} \mathrm{L}-1$ ) (Olguín et al., 2007). The greater sorption capacity of Salvinia biomass can be explored to use it as oil filter for removal of oil from oil/water emulsions. The superiority of the Salvinia sp. for removing oil (approx. 90\% of the oil was retained by the biomass) from such emulsions appears to be due to large surface area, hydrophobicity of the aquaphyte biomass and hair-like surface that results in space between the hairs to hold oil (Ribeiro et al., 2003).

The bioremediation (phytoremediation) of heavy metals in India has not been thoroughly investigated and hence the present study was undertaken to evaluate the efficacy of the three Indian species of Salvinia, viz., S. natans, S. molesta and $S$. auriculata to accumulate heavy metals.

\section{Materials and Methods}

The three species of Salvinia viz., Salvinia natans, S. molesta and S. auriculata of uniform size, mass and root length were collected from different lakes of Srinagar and Kerala ( $S$. natans from Srinagar and $S$. molesta and S. auriculata from Kerala.

The plants thus collected were washed several times in tap water and finally in deionized distilled water to remove the impurities periphyton, dust and sediment particles. The material was stored in polythene bags, at the same time the water samples around the plants were collected randomly and brought to laboratory. The temperature of water at the time of sampling was recorded. All individual plant samples were again washed with distilled deionized water in laboratory.

The molar stock solution of each of the heavy metal salts viz., Cadmium chloride, potassium dichromate, Copper sulphate, Mercuric chloride Lead chloride, Nickel chloride and Zinc chloride was prepared by dissolving 138.32g, 294.185g, 159.609g, $271.52 \mathrm{~g}, 278.1 \mathrm{~g}, 129.599 \mathrm{~g}$ and $136.315 \mathrm{~g}$ respectively in $1000 \mathrm{ml}$ of distilled water separately. From these molar stock solution four different concentrations of each of the heavy metal salt solution such as $25 \mathrm{mg} / \mathrm{l}, 50$ $\mathrm{mg} / \mathrm{l}, 75 \mathrm{mg} / \mathrm{l}$ and $100 \mathrm{mg} / \mathrm{l}$ were prepared separately.

The water fern Salvinia natans, S. molesta and $S$. auriculata of more or less uniform size and equal number were treated with different concentration of each of the heavy metal salts separately in aquarium. The setup was left undisturbed in a shaded area for 10 days. After 10 days of treatment with heavy metal salts the plants were harvested from each container separately. Plants were then washed with distilled water to remove excess salts present around it. With the help of tissue paper the excess water was removed from the plant. The treated plants were then analysed.

After 10 days of treatment each plant sample from control and plants treated with different concentrations heavy metal salts were carefully taken and the fresh weight of the plant samples were analysed using a monobalance.

The fresh plants from both the control and plants treated with different concentrations of heavy metal salts viz., 25\%, $50 \%, 75 \%$ and $100 \%$ were taken and dried first in sun light for 10 days and then in hot air oven at $110^{\circ} \mathrm{C}$ for 12 hours. The dry weight of the samples were analysed using a monobalance. 


\section{AS Analysis}

The dried samples of Salvinia natans, Salvinia molesta and Salvinia auriculata and were weighed accurately and dissolved in $\mathrm{HNO}_{3}$ and $\mathrm{HClO}_{4}$ (in the ratio 3:1). The resulting mixtures were evaporated to dryness and extracted with distilled, deionized water. The solutions were heated to boiling and filtered. The volumes of the diluted sample were made to $100 \mathrm{~mL}$ each. $1.0 \mathrm{~L}$ water sample was heated to reduce the volume, acidified and total $100 \mathrm{~mL}$ volume was made. The metal ion concentrations in all the samples were analyzed by Atomic Absorption Spectrometer. For determination of unknown concentrations of all metals, the calibration charts for each element were used. All analyses were done in triplicate and one blank sample.

For the analysis of heavy metals, plant samples were powdered with the help of ash test. Plant samples were placed in china dishes and heated in a muffle furnace for a period of 5 hours. The ash thus obtained was digested using $2 \mathrm{ml}$ of concentrated $\mathrm{HCl}$. The acid-ash solution was diluted and made up to $100 \mathrm{ml}$ solution. The solution was then used to record the amount of Cadmium, Chromium, Copper, Mercury, Lead, Nickel and Zinc accumulation in the samples.

The analysis of heavy metals was done using The Atomic Absorption Spectrometer (AAS). GBC 933A AAS model was used for the determination of heavy metals. It consist of a glass electrode Sargent-Welch digital $\mathrm{pH}$ meter, model Pax S-29998 with $\mathrm{pH}$ reading to 0.01 in the range of 0 to 14 was used.

The standard stock solutions of the metal containing samples were prepared for examination of heavy metal based on American Public Health Association APHA (1985).

\section{Results and Discussion}

From the results it is evident that various concentrations of heavy metals used in the present investigation caused considerable reduction in the fresh weight and increase in dry weight of all the three species of Salvinia viz., S. natans, S. molesta and $S$. auriculata. With increase in the concentration of the heavy metal, a decrease in the fresh weights of Salvinia was noticed. The results obtained have been presented in Tables- 1-14.

The control plants of Salvinia natans, $S$. molesta and S. auriculata showed healthy growth and significant biomass i.e. $22.25 \mathrm{~g}$, $21.50 \mathrm{~g}$ and $21.55 \mathrm{~g}$ respectively. At $25 \%$ Cadmium salt S. natans, S. molesta and $S$. auriculata showed a decrease in fresh weight to $16.50 \mathrm{~g}, 17.25 \mathrm{~g}$ and $16.25 \mathrm{~g}$ respectively. All the three species of Salvinia showed a decline in fresh weight with increasing concentration of Cadmium. At $100 \%$ concentration the Cadmium caused a significant decline in the biomass of all the three species (S. natans, $11.25 \mathrm{~g}$, S. molesta, $10.25 \mathrm{~g}$ and $\mathrm{S}$. auriculata, $11.50 \mathrm{~g}$ ) (Table- 1). Similarly this heavy metals caused an increase in the dry weight with gradual increase in concentration of Cadmium. At $100 \%$ concentration of Cadmium S. natans, S. molesta and S. auriculata showed an increase in their dry weight to $1.30 \mathrm{~g}, 2.07 \mathrm{~g}$ and $1.85 \mathrm{~g}$ respectively (Table-1). All the three species showed a similar trend in reduction of biomass and enhancement of dry weight in response to other heavy metals selected in the present investigation viz., Chromium, Copper, Mercury, Lead, Nickel and Zinc (Table 2 to 7). At 100\% concentration of Chromium, Mercury, Lead, Nickel and Zinc salts all the three species of Salvinia showed a significant reduction in their biomass to $10.35-11.25 \mathrm{~g}, \quad 9.25-$ $11.25 \mathrm{~g}, 0.85-11.50 \mathrm{~g}, 11.25-11.50 \mathrm{~g}, 10.25-$ 
$12.25 \mathrm{~g}$ and $10.25-11.50 \mathrm{~g}$ respectively (Table-2 to 7). However, Mercury (Hg) and Copper $(\mathrm{Cu})$ caused maximum reduction in the biomass of Salvinia natans (Table- 3 and 4). The present findings gain support from the work of Ranjana Julias Thilakar et al.,
(2012) who have found a similar trend of reduction in biomass of Pistia stratiotes L. and Salvinia natans (L.) All. In response to phytoaccumulation of Chromium and Copper.

Table.1 Effect of Cadmium on the Biomass of the three species of Salvinia

\begin{tabular}{|l|l|l|l|l|l|l|}
\hline $\begin{array}{l}\text { Conc. } \\
\text { Cd }(\%)\end{array}$ & \multicolumn{3}{|l|}{ S. natans } & \multicolumn{2}{l|}{ molesta } & \multicolumn{2}{l|}{. auriculata } \\
\cline { 2 - 7 } & $\begin{array}{l}\text { Fresh } \\
\text { weight }(\mathrm{g})\end{array}$ & $\begin{array}{l}\text { Dry } \\
\text { weight }(\mathrm{g})\end{array}$ & $\begin{array}{l}\text { Fresh } \\
\text { weight }(\mathrm{g}\end{array}$ & $\begin{array}{l}\text { Dry } \\
\text { weight }(\mathrm{g})\end{array}$ & $\begin{array}{l}\text { Fresh } \\
\text { weight }(\mathrm{g}\end{array}$ & $\begin{array}{l}\text { Dry } \\
\text { weight }(\mathrm{g})\end{array}$ \\
\hline Control & $\mathbf{2 2 . 2 5} \pm \mathbf{1 . 0 4}$ & $\mathbf{0 . 6 5} \pm \mathbf{0 . 1 5}$ & $\mathbf{2 1 . 5 0} \pm \mathbf{1 . 0 6}$ & $\mathbf{0 . 6 3} \pm \mathbf{0 . 1 4}$ & $\mathbf{2 1 . 5 5} \pm \mathbf{1 . 0 7}$ & $\mathbf{0 . 6 0} \pm \mathbf{0 . 1 6}$ \\
\hline $\mathbf{2 5}$ & $\mathbf{1 6 . 5 0} \pm \mathbf{1 . 4 0}$ & $\mathbf{1 . 0 7} \pm \mathbf{0 . 1 5}$ & $\mathbf{1 7 . 2 5} \pm \mathbf{1 . 0 5}$ & $\mathbf{1 . 6 5} \pm \mathbf{0 . 0 5}$ & $\mathbf{1 6 . 2 5} \pm \mathbf{1 . 0 2}$ & $\mathbf{0 . 6 1} \pm \mathbf{0 . 0 3}$ \\
\hline $\mathbf{5 0}$ & $\mathbf{1 5 . 5 0} \pm \mathbf{1 . 2 5}$ & $\mathbf{1 . 0 8} \pm \mathbf{0 . 0 7}$ & $\mathbf{1 6 . 4 5} \pm \mathbf{1 . 0 4}$ & $\mathbf{1 . 9 0} \pm \mathbf{0 . 0 5}$ & $\mathbf{1 5 . 6 5} \pm \mathbf{1 . 0 5}$ & $\mathbf{1 . 0 4} \pm \mathbf{0 . 0 5}$ \\
\hline $\mathbf{7 5}$ & $\mathbf{1 3 . 1 5} \pm \mathbf{1 . 1 0}$ & $\mathbf{1 . 2 0} \pm \mathbf{0 . 0 6}$ & $\mathbf{1 4 . 5 0} \pm \mathbf{1 . 0 5}$ & $\mathbf{1 . 9 6} \pm \mathbf{0 . 0 4}$ & $\mathbf{1 3 . 1 4} \pm \mathbf{1 . 0 2}$ & $\mathbf{1 . 5 0} \pm \mathbf{0 . 0 2}$ \\
\hline 100 & $\mathbf{1 1 . 2 5} \pm \mathbf{1 . 1 2}$ & $\mathbf{1 . 3 0} \pm \mathbf{0 . 0 4}$ & $\mathbf{1 0 . 2 5} \pm \mathbf{1 . 0 3}$ & $\mathbf{2 . 0 7} \pm \mathbf{0 . 1 3}$ & $\mathbf{1 1 . 5 0} \pm \mathbf{1 . 0 6}$ & $\mathbf{1 . 8 5} \pm \mathbf{0 . 0 3}$ \\
\hline
\end{tabular}

Table.2 Effect of Chromium on the Biomass of the three species of Salvinia

\begin{tabular}{|c|c|c|c|c|c|c|}
\hline \multirow{2}{*}{$\begin{array}{l}\text { Conc. of } \\
\operatorname{Cr}(\%)\end{array}$} & \multicolumn{2}{|l|}{ S. natans } & \multicolumn{2}{|l|}{ S. molesta } & \multicolumn{2}{|l|}{ S. auriculata } \\
\hline & $\begin{array}{l}\text { Fresh } \\
\text { weight (g) }\end{array}$ & $\begin{array}{l}\text { Dry } \\
\text { weight (g) }\end{array}$ & $\begin{array}{l}\text { Fresh } \\
\text { weight (g }\end{array}$ & $\begin{array}{l}\text { Dry } \\
\text { weight (g) }\end{array}$ & $\begin{array}{l}\text { Fresh weight } \\
\text { (g }\end{array}$ & $\begin{array}{l}\text { Dry } \\
\text { weight }(g)\end{array}$ \\
\hline Control & $22.25 \pm 1.05$ & $0.67 \pm 0.15$ & $21.50 \pm 1.05$ & $0.63 \pm 0.14$ & $21.55 \pm 1.05$ & $0.60 \pm 0.16$ \\
\hline 25 & $16.55 \pm 1.40$ & $1.04 \pm 0.15$ & $17.55 \pm 1.05$ & 1.60 .05 & $16.55 \pm 1.02$ & $0.60 \pm 0.03$ \\
\hline 50 & $14.50 \pm 1.20$ & $1.08 \pm 0.07$ & $15.45 \pm 1.02$ & $1.03 \pm 0.05$ & $15.75 \pm 1.02$ & $1.05 \pm 0.05$ \\
\hline 75 & $12.15 \pm 1.12$ & $1.01 \pm 0.06$ & $12.50 \pm 1.03$ & $1.05 \pm 0.04$ & $13.24 \pm 1.02$ & $1.00 \pm 0.02$ \\
\hline 100 & $10.35 \pm 1.12$ & $1.00 \pm 0.04$ & $10.55 \pm 1.04$ & $1.02 \pm 0.13$ & $11.25 \pm 1.04$ & $0.85 \pm 0.03$ \\
\hline
\end{tabular}

Table.3 Effect of Copper on the Biomass of the three species of Salvinia

\begin{tabular}{|l|l|l|l|l|l|l|}
\hline $\begin{array}{l}\text { Conc. } \\
\text { Cu }(\%)\end{array}$ & \multicolumn{3}{|l|}{ S. natans } & \multicolumn{2}{l|}{ molesta } & \multicolumn{2}{l|}{. auriculata } \\
\cline { 2 - 7 } & $\begin{array}{l}\text { Fresh } \\
\text { weight }(\mathrm{g})\end{array}$ & $\begin{array}{l}\text { Dry } \\
\text { weight }(\mathrm{g})\end{array}$ & $\begin{array}{l}\text { Fresh } \\
\text { weight }(\mathrm{g}\end{array}$ & $\begin{array}{l}\text { Dry } \\
\text { weight }(\mathrm{g})\end{array}$ & $\begin{array}{l}\text { Fresh } \\
\text { weight }(\mathrm{g}\end{array}$ & $\begin{array}{l}\text { Dry } \\
\text { weight }(\mathrm{g})\end{array}$ \\
\hline Control & $\mathbf{2 2 . 2 5} \pm \mathbf{1 . 0 5}$ & $\mathbf{0 . 6 7} \pm \mathbf{0 . 1 5}$ & $\mathbf{2 1 5 0} \pm \mathbf{1 . 0 6}$ & $\mathbf{0 . 6 3} \pm \mathbf{0 . 1 1}$ & $\mathbf{2 1 . 5 5} \pm \mathbf{1 . 0 7}$ & $\mathbf{0 . 6 0} \pm \mathbf{0 . 1 3}$ \\
\hline $\mathbf{2 5}$ & $\mathbf{1 4 . 5 0} \pm \mathbf{1 . 4 0}$ & $\mathbf{0 . 8 5} \pm \mathbf{0 . 1 5}$ & $\mathbf{1 6 . 2 5} \pm \mathbf{1 . 0 5}$ & $\mathbf{1 . 6 2} \pm \mathbf{0 . 0 6}$ & $\mathbf{1 5 . 2 5} \pm \mathbf{1 . 0 2}$ & $\mathbf{0 . 6 5} \pm \mathbf{0 . 0 5}$ \\
\hline $\mathbf{5 0}$ & $\mathbf{1 2 . 5 0} \pm \mathbf{1 . 1 5}$ & $\mathbf{0 . 8 7} \pm \mathbf{0 . 0 7}$ & $\mathbf{1 4 . 4 5} \pm \mathbf{1 . 0 4}$ & $\mathbf{1 . 0 5} \pm \mathbf{0 . 0 4}$ & $\mathbf{1 4 . 6 5} \pm \mathbf{1 . 0 5}$ & $\mathbf{1 . 0 7} \pm \mathbf{0 . 0 3}$ \\
\hline $\mathbf{7 5}$ & $\mathbf{1 0 . 1 5} \pm \mathbf{1 . 0 5}$ & $\mathbf{1 . 0 2} \pm \mathbf{0 . 0 6}$ & $\mathbf{1 2 . 5 0} \pm \mathbf{1 . 0 5}$ & $\mathbf{1 . 0 8} \pm \mathbf{0 . 0 2}$ & $\mathbf{1 2 . 1 4} \pm \mathbf{1 . 0 2}$ & $\mathbf{1 . 8 5} \pm \mathbf{0 . 0 4}$ \\
\hline 100 & $\mathbf{9 . 2 5} \pm \mathbf{1 . 1 1}$ & $\mathbf{1 . 0 5} \pm \mathbf{0 . 0 4}$ & $\mathbf{1 1 . 2 5} \pm \mathbf{1 . 0 3}$ & $\mathbf{1 . 5 0} \pm \mathbf{0 . 0 5}$ & $\mathbf{1 0 . 5 0} \pm \mathbf{1 . 0 6}$ & $\mathbf{2 . 5 0 \pm 0 . 0 3}$ \\
\hline
\end{tabular}


Table.4 Effect of Mercury on the Biomass of the three species of Salvinia

\begin{tabular}{|c|c|c|c|c|c|c|}
\hline \multirow{2}{*}{$\begin{array}{l}\text { Conc. of } \\
\mathrm{Hg}(\%)\end{array}$} & \multicolumn{2}{|l|}{ S. natans } & \multicolumn{2}{|l|}{ S. molesta } & \multicolumn{2}{|c|}{ S. auriculata } \\
\hline & $\begin{array}{l}\text { Fresh } \\
\text { weight (g) }\end{array}$ & $\begin{array}{l}\text { Dry } \\
\text { weight (g) }\end{array}$ & $\begin{array}{l}\text { Fresh } \\
\text { weight (g }\end{array}$ & $\begin{array}{l}\text { Dry } \\
\text { weight (g) }\end{array}$ & $\begin{array}{l}\text { Fresh } \\
\text { weight (g }\end{array}$ & $\begin{array}{l}\text { Dry } \\
\text { weight }(g)\end{array}$ \\
\hline Control & $23.25 \pm 1.04$ & $0.65 \pm 0.15$ & $25.50 \pm 1.06$ & $0.64 \pm 0.15$ & $24.55 \pm 1.07$ & $0.60 \pm 0.16$ \\
\hline 25 & $15.50 \pm 1.22$ & $1.02 \pm 0.15$ & $17.25 \pm 1.05$ & $1.64 \pm 0.10$ & $16.25 \pm 1.02$ & $0.65 \pm 0.03$ \\
\hline 50 & $13.50 \pm 1.21$ & $\mathbf{1 . 0 5} \pm 0.07$ & $16.75 \pm 1.04$ & $1.80 \pm 0.05$ & $15.65 \pm 1.05$ & $1.04 \pm 0.05$ \\
\hline 75 & $11.15 \pm 0.10$ & $1.50 \pm 0.06$ & $14.25 \pm 1.05$ & $2.00 \pm 04$ & $13.14 \pm 1.02$ & $1.50 \pm 0.02$ \\
\hline 100 & $0.85 \pm 0.12$ & $1.80 \pm 0.04$ & $10.05 \pm 1.03$ & $2.51 \pm 0.13$ & $11.50 \pm 1.06$ & $2.25 \pm 0.03$ \\
\hline
\end{tabular}

Table.5 Effect of Lead on the Biomass of the three species of Salvinia

\begin{tabular}{|c|c|c|c|c|c|c|}
\hline \multirow{2}{*}{$\begin{array}{l}\text { Conc. of } \\
\mathrm{Pb}(\%)\end{array}$} & \multicolumn{2}{|l|}{ S. natans } & \multicolumn{2}{|l|}{ S. molesta } & \multicolumn{2}{|l|}{ S. auriculata } \\
\hline & $\begin{array}{l}\text { Fresh } \\
\text { weight (g) }\end{array}$ & $\begin{array}{l}\text { Dry } \\
\text { weight (g) }\end{array}$ & $\begin{array}{l}\text { Fresh } \\
\text { weight (g }\end{array}$ & $\begin{array}{l}\text { Dry } \\
\text { weight (g) }\end{array}$ & $\begin{array}{l}\text { Fresh } \\
\text { weight (g }\end{array}$ & $\begin{array}{l}\text { Dry } \\
\text { weight (g) }\end{array}$ \\
\hline Control & $25.25 \pm 1.04$ & $0.75 \pm 0.15$ & $24.50 \pm 1.06$ & $0.73 \pm 0.14$ & $25.55 \pm 1.07$ & $0.60 \pm 0.16$ \\
\hline 25 & $18.50 \pm 1.40$ & $1.05 \pm 0.15$ & $18.25 \pm 1.05$ & $1.65 \pm 0.05$ & $16.25 \pm 1.02$ & $0.65 \pm 0.03$ \\
\hline 50 & $14.50 \pm 1.25$ & $\mathbf{1 . 5 7} \pm \mathbf{0 . 0 7}$ & $15.45 \pm 1.04$ & $1.79 \pm 0.05$ & $15.65 \pm 1.05$ & $1.04 \pm 0.05$ \\
\hline 75 & $12.15 \pm 1.10$ & $1.75 \pm 0.06$ & $13.50 \pm 1.05$ & $2.06 \pm 0.04$ & $13.14 \pm 1.02$ & $1.50 \pm 0.02$ \\
\hline 100 & $11.25 \pm 1.12$ & $2.00 \pm 0.04$ & $11.25 \pm 1.03$ & $2.27 \pm 0.13$ & $11.50 \pm 1.06$ & $2.85 \pm 0.03$ \\
\hline
\end{tabular}

Table.6 Effect of Nickel on the Biomass of the three species of Salvinia

\begin{tabular}{|c|c|c|c|c|c|c|}
\hline \multirow{2}{*}{$\begin{array}{ll}\text { Conc. of } \\
\mathrm{Ni}(\%)\end{array}$} & \multicolumn{2}{|l|}{ S. natans } & \multicolumn{2}{|l|}{ S. molesta } & \multicolumn{2}{|c|}{ S. auriculata } \\
\hline & $\begin{array}{l}\text { Fresh } \\
\text { weight (g) }\end{array}$ & $\begin{array}{l}\text { Dry } \\
\text { weight (g) }\end{array}$ & $\begin{array}{l}\text { Fresh } \\
\text { weight (g }\end{array}$ & $\begin{array}{l}\text { Dry } \\
\text { weight (g) }\end{array}$ & $\begin{array}{l}\text { Fresh } \\
\text { weight (g }\end{array}$ & $\begin{array}{l}\text { Dry } \\
\text { weight (g) }\end{array}$ \\
\hline Control & $23.25 \pm 1.04$ & $0.65 \pm 0.15$ & $22.50 \pm 1.06$ & $0.63 \pm 0.14$ & $23.55 \pm 1.07$ & $0.60 \pm 0.16$ \\
\hline 25 & $17.50 \pm 1.40$ & $1.05 \pm 0.15$ & $17.25 \pm 1.05$ & $1.05 \pm 0.05$ & $16.25 \pm 1.02$ & $0.64 \pm 0.03$ \\
\hline 50 & $16.50 \pm 1.25$ & $1.07 \pm 0.07$ & $16.45 \pm 1.04$ & $1.50 \pm 0.05$ & $15.60 \pm 1.05$ & $1.54 \pm 0.05$ \\
\hline 75 & $14.15 \pm 1.10$ & $1.85 \pm 0.06$ & $14.50 \pm 1.05$ & $1.86 \pm 0.04$ & $13.15 \pm 1.02$ & $1.70 \pm 0.02$ \\
\hline 100 & $12.25 \pm 1.12$ & $2.00 \pm 0.04$ & $10.25 \pm 1.03$ & $2.27 \pm 0.13$ & $11.55 \pm 1.06$ & $2.55 \pm 0.03$ \\
\hline
\end{tabular}

Table.7 Effect of Zinc on the Biomass of the three species of Salvinia

\begin{tabular}{|c|c|c|c|c|c|c|}
\hline \multirow{2}{*}{$\begin{array}{l}\text { Conc. of } \\
\operatorname{Zn}(\%)\end{array}$} & \multicolumn{2}{|l|}{ S. natans } & \multicolumn{2}{|l|}{ S. molesta } & \multicolumn{2}{|c|}{ S. auriculata } \\
\hline & $\begin{array}{l}\text { Fresh } \\
\text { weight (g) }\end{array}$ & $\begin{array}{l}\text { Dry } \\
\text { weight (g) }\end{array}$ & $\begin{array}{l}\text { Fresh } \\
\text { weight (g) }\end{array}$ & $\begin{array}{l}\text { Dry } \\
\text { weight (g) }\end{array}$ & $\begin{array}{l}\text { Fresh } \\
\text { weight (g }\end{array}$ & $\begin{array}{l}\text { Dry } \\
\text { weight (g) }\end{array}$ \\
\hline Control & $22.25 \pm 1.04$ & $0.65 \pm 0.12$ & $21.50 \pm 1.06$ & $0.64 \pm 0.14$ & $21.55 \pm 1.07$ & $0.60 \pm 0.16$ \\
\hline 25 & $17.20 \pm 1.40$ & $1.05 \pm 0.13$ & $17.25 \pm 1.05$ & $1.05 \pm 0.05$ & $16.25 \pm 1.02$ & $0.75 \pm 0.03$ \\
\hline 50 & $16.30 \pm 1.25$ & $1.57 \pm 0.05$ & $16.55 \pm 1.04$ & $1.50 \pm 0.05$ & $15.65 \pm 1.05$ & $1.55 \pm 0.05$ \\
\hline 75 & $13.25 \pm 1.10$ & $1.85 \pm 0.06$ & $13.50 \pm 1.05$ & $1.85 \pm 0.04$ & $13.14 \pm 1.02$ & $1.85 \pm 0.02$ \\
\hline 100 & $10.35 \pm 1.12$ & $2.00 \pm 0.02$ & $10.25 \pm 1.03$ & $2.07 \pm 0.13$ & $11.50 \pm 1.06$ & $2.85 \pm 0.03$ \\
\hline
\end{tabular}


Table.8 Bioaccumulation of Cadmium (in ppm) in three species of Salvinia

\begin{tabular}{|l|l|l|l|}
\hline $\begin{array}{l}\text { Conc. of } \\
\text { Cd }(\%)\end{array}$ & S. natans & S. molesta & S. auriculata \\
\hline Control & 0 & 0 & 0 \\
\hline 25 & $7250 \pm 1.71$ & $7565 \pm 1.65$ & $7350 \pm 1.62$ \\
\hline 50 & $9575 \pm 1.50$ & $10665 \pm 1.45$ & $9675 \pm 1.85$ \\
\hline 75 & $12350 \pm 1.70$ & $13340 \pm 1.66$ & $12465 \pm 1.55$ \\
\hline 100 & $16065 \pm 1.65$ & $17075 \pm 1.63$ & $16185 \pm 1.50$ \\
\hline
\end{tabular}

Table.9 Bioaccumulation of Chromium (in ppm) in three species of Salvinia

\begin{tabular}{|l|l|l|l|}
\hline $\begin{array}{l}\text { Conc. of } \\
\text { Cr }(\%)\end{array}$ & S. natans & S. molesta & S. auriculata \\
\hline Control & 0 & 0 & 0 \\
\hline 25 & $7350 \pm 1.75$ & $7565 \pm 1.63$ & $7350 \pm 1.65$ \\
\hline 50 & $9665 \pm 1.50$ & $10765 \pm 1.45$ & $9775 \pm 1.85$ \\
\hline 75 & $12550 \pm 1.75$ & $13540 \pm 1.66$ & $14565 \pm 1.55$ \\
\hline 100 & $16165 \pm 1.60$ & $17275 \pm 1.63$ & $17585 \pm 1.50$ \\
\hline
\end{tabular}

Table.10 Bioaccumulation of Copper (in ppm) in three species of Salvinia

\begin{tabular}{|l|l|l|l|}
\hline $\begin{array}{l}\text { Conc. of } \\
\text { Cu }(\%)\end{array}$ & S. natans & S. molesta & S. auriculata \\
\hline Control & 0 & 0 & 0 \\
\hline 25 & $7150 \pm 1.71$ & $7765 \pm 1.62$ & $7550 \pm 1.60$ \\
\hline 50 & $9275 \pm 1.50$ & $11645 \pm 1.40$ & $9875 \pm 1.81$ \\
\hline 75 & $11450 \pm 1.70$ & $13350 \pm 1.61$ & $13665 \pm 1.52$ \\
\hline 100 & $16265 \pm 1.65$ & $17375 \pm 1.61$ & $17285 \pm 1.51$ \\
\hline
\end{tabular}

Table.11 Bioaccumulation of Mercury (in ppm) in three species of Salvinia

\begin{tabular}{|l|l|l|l|}
\hline $\begin{array}{l}\text { Conc. of } \\
\text { Hg }(\%)\end{array}$ & S. natans & S. molesta & S. auriculata \\
\hline Control & 0 & 0 & 0 \\
\hline 25 & $7650 \pm 1.71$ & $7565 \pm 1.65$ & $7350 \pm 1.62$ \\
\hline 50 & $9775 \pm 1.50$ & $10665 \pm 1.45$ & $9675 \pm 1.85$ \\
\hline 75 & $14550 \pm 1.70$ & $15340 \pm 1.66$ & $14465 \pm 1.55$ \\
\hline 100 & $17265 \pm 1.65$ & $18575 \pm 1.63$ & $18185 \pm 1.50$ \\
\hline
\end{tabular}


Table.12 Bioaccumulation of Lead (in ppm) in three species of Salvinia

\begin{tabular}{|l|l|l|l|}
\hline $\begin{array}{l}\text { Conc. of } \\
\text { Pb }(\%)\end{array}$ & S. natans & S. molesta & S. auriculata \\
\hline Control & 0 & 0 & 0 \\
\hline 25 & $7250 \pm 1.71$ & $7565 \pm 1.67$ & $7350 \pm 1.65$ \\
\hline 50 & $9775 \pm 1.55$ & $10665 \pm 1.75$ & $9675 \pm 1.85$ \\
\hline 75 & $13450 \pm 1.70$ & $16340 \pm 1.65$ & $13565 \pm 1.55$ \\
\hline 100 & $17565 \pm 1.60$ & $18875 \pm 1.65$ & $17485 \pm 1.55$ \\
\hline
\end{tabular}

Table.13 Bioaccumulation of Nickel (in ppm) in three species of Salvinia

\begin{tabular}{|l|l|l|l|}
\hline $\begin{array}{l}\text { Conc. of } \\
\text { Ni }(\%)\end{array}$ & S. natans & S. molesta & S. auriculata \\
\hline Control & 0 & 0 & 0 \\
\hline 25 & $7550 \pm 1.75$ & $8565 \pm 1.65$ & $7650 \pm 1.62$ \\
\hline 50 & $9370 \pm 1.52$ & $11765 \pm 1.45$ & $10675 \pm 1.85$ \\
\hline 75 & $11355 \pm 1.75$ & $15350 \pm 1.66$ & $12465 \pm 1.55$ \\
\hline 100 & $14061 \pm 1.64$ & $18275 \pm 1.63$ & $16185 \pm 1.50$ \\
\hline
\end{tabular}

Table.14 Bioaccumulation of Zinc (in ppm) in three species of Salvinia

\begin{tabular}{|l|l|l|l|}
\hline $\begin{array}{l}\text { Conc. of } \\
\text { Zn }(\%)\end{array}$ & S. natans & S. molesta & S. auriculata \\
\hline Control & 0 & 0 & 0 \\
\hline 25 & $7550 \pm 1.70$ & $8565 \pm 1.65$ & $7750 \pm 1.62$ \\
\hline 50 & $9875 \pm 1.55$ & $10665 \pm 1.45$ & $9975 \pm 1.85$ \\
\hline 75 & $12450 \pm 1.75$ & $13340 \pm 1.66$ & $12765 \pm 1.55$ \\
\hline 100 & $16065 \pm 1.64$ & $17075 \pm 1.63$ & $16185 \pm 1.50$ \\
\hline
\end{tabular}

After 10 days of treatment the all the three species of Salvinia showed a substantial amount of accumulation of heavy metals in their tissues. The dried samples were powdered.and the ash was digested and the amount of metal accumulation was analysed using Atomic Absorption Spectrophotometer. A contact period of greater than 24 hour was necessary before the higher amount of heavy metal were detected in the plants (Sutton and Blackburn, 1971). Heavy metal concentration in plant tissues especially on shoot was noticed because of its direct contact with water as it was noticed by Kiran Gupta et al., (2012). This direct contact made the leaves of the plants fragile and change in colour. As explained by Sinha et al., (2006) this is due to decrease in chlorophyll content with increase in concentration of heavy metals. In the present investigation it was found that the bioaccumulation of heavy metals increased with increasing their concentrations.

At $100 \%$ maximum accumulation of heavy metals was noticed in all the three species. Salvinia natans, S. molesta and S. auriculata showed 16065ppm, 17075ppm and $16185 \mathrm{ppm}$ of $\mathrm{Cd}$ in their tissues respectively at $100 \%$ concentration. A more or less similar pattern of bioaccumulation of all the 
heavy metals selected for present investigation was recorded (Table 8-14). Salvinia molesta showed maximum accumulation of $\mathrm{Hg}, \mathrm{Ni}$ and $\mathrm{Pb}$ in the concentration of $18575 \mathrm{ppm}, 18875 \mathrm{ppm}$ and $18275 \mathrm{ppm}$ respectively. A more or less similar pattern of accumulation of Chromium and Copper was recorded in Pistia stratiotes and Salvinia natans by Ranjana Julias Thilakar et al., (2012). The present findings are also in accordance with Preetha and Kaladevi (2014) and Bhupinder Dhir (2009) who observed a similar pattern of bioaccumulation of heavy metals by Salvinia molesta S. minima $S$. auriculata $S$. herzogii S. rotundifolia S. natans.

Therefore, from the results it can be concluded that Salvinia natans S. molesta and $S$. auriculata are efficient in accumulating highest amounts of heavy metals. The results obtained in the experimental study proves the fact that Salvinia natans, $S$. molesta and $S$. auriculata have the innate capacity for the accumulation of appreciable quantities of heavy metals. The species of Salvinia performs better Rhizofiltration to absorb, concentrate, and precipitate toxic metals from contaminated water. They are natural hyperaccumulators of many heavy and toxic metals. Therefore they can be effectively employed in phytoremediation of polluted water bodies. Initially, suitable plants with stable root systems can be supplied with contaminated water to acclimate the plants. Then these plants can be transferred to the contaminated site to collect the contaminants, and once the roots are saturated, they can be harvested. Rhizofiltration allows in-situ treatment, minimizing disturbance to the environment. The only drawback of using these plants for phytoremediation is that the species of Salvinia are invasive. They rapidly colonise aquatic ecosystems and reduce the populations of native plants. However, Salvinia natans, S. molesta and S. auriculata have a high biomass and can effectively be used for the production of biofuels, especially bio-ethanol and bio-methanol.

With urbanization and industrialization heavy metal accumulation has become a global issue. The release of heavy metals like $\mathrm{Cr}, \mathrm{Cu}, \mathrm{Zn}, \mathrm{Pb}, \mathrm{Cd}, \mathrm{Ni}, \mathrm{Hg}$ etc into the environment has increased the degradation of living and non living organism. Water is the elixir of life and an universal solvent that carries nutrients and wastes to and from our cells. In recent years water pollution has become a great issue. To control and remove the heavy metals several conventional methods are used which include chemical precipitation, lime coagulation, ion exchange, reverse osmosis solvent extraction, aeration, chemical oxidation, electrolysis, ultra filtration, and chlorination. But the cheapest method is phytoremediation.

This process uses plants to remove the heavy metals by the process called bioaccumulation. The present study has shown that the species of Salvinia are highly invasive, and can effectively be employed in the phytoremediation of aquatic ecosystem which have been polluted by harmful, toxic heavy metals like Chromium, Copper, zinc, Mercury, Lead etc. The plants were treated in different chemical composition and the phytoaccumulation was noted. Properties such as high productivity, high absorption capacity and high metal removal potential establish species of Salvinia as a macrophyte with immense potential for use in phytoremediation technologies. The resulting metal treated biomass can be safely smelted later. They can also be used to produce biofuels like bioethanol and biomethanol by the action of certain genetically engineered microbes. In this 
manner pollution can be mitigated and aquatic ecosystem can be protected.

\section{Acknowledgment}

The first author is grateful to Dr. Baidyanath Kumar, Visiting Professor, Department of Biotechnology, Patna Science College (Patna University), Patna for providing necessary suggestions.

\section{References}

APHA. 1985. Standard method for the examination of water and waste water. 16Ed American Public Health Association, Washington DC, USA.

Banerjee, G., Sarker, S. 1997. The role of Salvinia rotundifolia in scavenging aquatic $\mathrm{Pb}$ (II) pollution: a case study. Bioprocess Engi., 17: 295-300.

Benaroya, R.O., Tzin, V., Tel-Or, E., Zamski, E. 2004. Lead accumulation in the aquaticfern Azolla filiculoides. Plant Physiol. Biochem., 42: 639-645.

Bequer, T., C. Quantin, M. Sicot, J.P. Boudot. 2003. Sci. Total Environ., 301: 251-61.

Bhupinder Dhir. 2009. Salvinia: an Aquatic Fern with Potential Use in Phytoremediation Environ. Int. J. Sci. Tech., 4: 23-27.

Chaney, R.L. 1983. Land Treatment of Hazardous Wastes, P. 152-240.

David, A., Wright, Pamela Welbourn. 2002. Environmental Toxicology, Cambridge University Press, Cambridge, U.K.

Dushenkov, V.P., Nandakumar, B.A., Motto, H., Raskin, I. 1995. Rhizofilltration: The use of plants to remove heavy metals from aqueous streams. Environ. Sci. Technol., 29: 1239-1241.

Espinoza-Quinones, F.R., Zacarlein, C.E., Palacio, S.M., Obregon, C.L., Zenatti,
D.C., Galante, R.M., Rossi, N., Rossi, F.L., Pereira, R.A., Welter, R.A., Rizzulto, M.A. 2005. Removal of heavy metals from polluted river using aquatic macrophytes Salvinia sp. Brazilian J. Plant Physiol., 35: 744746.

Heike Bradl. 2005. Heavy metals in the environment: Origin, Interaction and Remediation, 1st Edn. Academic Press,

Hoffmann, T., Kutter, C., Santamaria, J.M. 2004. Capacity of Salvinia minima Baker to tolerate and accumulate As and $\mathrm{Pb}$. Engi. Life Sci., 4: 61-65.

Jacobson, M.E., Chiang, S.Y., Gueriguian, L., Westholm, L.R., Pierson, J., Zhu, G., Saunders, F.M. 2003. Transformation Kinetics of Trinitrotoluene Conversion in Aquatic Plants In Phytoremediation, eds. S. C. McCutcheon, J.L. Schnoor, JohnWiley-and Sons, Inc. Kiran Gupta, Sumati Gaumat, Kumkum Mishra (2012. India J. Environ. Biol., 32: 591597.

Lasat, M.M. 2002. J. Environ. Qual., 31: 109-120.

Maine, M.A., Suñe, N.L., Lagger, S.C. 2004. Chromium bioaccumulation: comparison of the capacity of two free-floating macrophytes. Water Res., 38: 1494-1501.

Molisani, M.M., Rocha, R., Machado, W., Barreto, R.C., Lacerda, L.D. 2006. Mercury contents in aquatic macrophytes from two resevoirs in the paraiba do sul: Guandu river system, Se Brazil. Brazilian J. Biol., 66: 101107.

Mukherjee, S., Kumar, S. 2005. Adsorptive uptake of arsenic (V) from water by aquatic fern Salvinia natans. J. Water Supply: Res. Technol., 54: 47-53.

Nichols, P.B., Couch, J. D., Al-Hamdani, S. H. 2000. Selected physiological 
responses of Salvinia minima to different chromium concentrations. Aquatic Bot., 68: 313-319.

Olguı'n, E.J., Sa'nchez-Galva'n, G., Pe'rezPe'rez, T., Pe'rez-Orozco, A. 2005. Surface adsorption, intracellular accumulation and compartmentalization of $\mathrm{Pb}$ (II) in batch-operated lagoons with Salvinia minima as affected by environmental conditions, EDTA and nutrients. $J$. Industrial and Microbiol. Biotechnol., 32: 577-586.

Olguin, E.J., Rodriguez, D., Sanchez, G., Hernandez, E., Ramirez, M.E. 2003. Productivity, protein content and nutrient removal from anaerobic effluents of coffee wastewater in Salvinia minima ponds, under subtropical conditions. Acta Biotechnol., 23: 259-270.

Olguín, E.J., Sánchez-Galván, G., PérezPérez, P. 2007. Assessment of the phytoremediation potential of Salvinia minima Baker compared to Spirodela polyrrhiza in high-strength Organic Wastewater. Water, Air and Soil Pollu., 181: 135-147.

Olguin, J., Hernandez, E., Ramos, I. 2002. The effect of both different light conditions and the $\mathrm{pH}$ value on the capacity of Salvinia minima BAKER for removing cadmium, lead and chromium. Acta Biotechnol., 22: 121131.

Pink, H., Daniel. 2006. Investing in tomorrow's liquid gold, in the yahoo blog, p.3.

Preetha, S., and Kaladevi. V. 2014. Phytoremediation of Heavy Metals Using Aquatic Macrophytes, World J. Environ. Biosci., (3)1: 34-41.

Rai, U.N., Sinha, S., Tripathi, R.D., Chandra, P. 1995. Wastewater treatability potential of some aquatic macrophytes: removal of heavy metals. Ecol. Engi., 5: 5-12.

Ranjana Julias Thilakar, Jeya Rathi. J. and Prabha, M., Pillai. 2012. Phytoaccumulation of Chromium and Copper by Pistia stratiotes L. and Salvinia natans (L.) All. Scholars Research Library J. Nat. Prod. Plant Resour., 2(6):725-730.

Ribeiro, T.H., Rubio, J. Smith, R.W. 2003. A Dried Hydrophobic Aquaphyte as Oil Filter for Oil/Water Emulsions Spill. Sci. Technol. Bull., 8: 483-489.

Sánchez-Galván, G., Monroy, O., Gómez, G., Olguín, E.J. 2008. Assessment of the hyperaccumulating lead capacity of Salvinia minima using bioadsorption and intracellular accumulation factors. Water, Air and Soil Pollu., 194: 77-90.

Schneider, I.A.H., Rubio, J. 1999. Sorption of Heavy Metal ions by the nonliving biomass of freshwater macrophytes. Environ. Sci. Technol., 33: 2213-2217.

Sinha, S., A.K. Gupta, K. Bhatt, K. Pandey, U.N. Rai, K.P. Singh. 2006. Environ. Monitor. Assess., 80: 17-31.

Skinner, K., Wright, N., Porter-Goff, E. 2007. Mercury uptake and accumulation by four aquatic plants. Environ. Pollu., 145: 234-237.

Srivastav, R.K., Gupta, S.K., Nigam, K.D.P. and Vasudevan, P. 1993. Use of aquatic plants for the removal of heavy metals from wastewater. Int. J. Environ. Studies, 45: 43-50.

Stepniewska, Z., Bennicelli, R.P., Balakhnina, T.I., Szajnocha, K., Banach, A., Wolinska, A. 2005. Potential of Azolla caroliniana for the removal of $\mathrm{Pb}$ and $\mathrm{Cd}$ from wastewaters. Int. Agrophysics, 19: 251-255.

Suñe, N., Sa'nchez, G., Caffaratti, S., Maine, M.A. 2007. Cadmium and chromium removal kinetics from solution by two aquatic macrophytes. 
Environ. Pollu., 145: 467-473.

Sutton, D., R. Blackburn. 1971. Hyacinth

Contr. J., 9: 18-19.

Xu, Q.S., Ji, W.D., Yang, H.Y., Wang, H.

X., Xu, Y., Zhao, J., Shi, G.X. 2009.
Cadmium accumulation and phytotoxicity in an aquatic fern, Salvinia natans (Linn.). Acta Ecologica Sinica, 29: 3019-3027.

\section{How to cite this article:}

Sweta Kumari, Baidyanath Kumar and Rimjhim Sheel. 2016. Bioremediation of Heavy Metals by Serious Aquatic Weed, Salvinia. Int.J.Curr.Microbiol.App.Sci. 5(9): 355-368. doi: http://dx.doi.org/10.20546/ijcmas.2016.509.039 